Portland State University

PDXScholar

\title{
Colorism in Mexico: An Examination of Inequality and the Psychological Impact in the Form of Depression
}

Ana K. Kinzie

Portland State University

Follow this and additional works at: https://pdxscholar.library.pdx.edu/honorstheses

Part of the Multicultural Psychology Commons, and the Race and Ethnicity Commons Let us know how access to this document benefits you.

\section{Recommended Citation}

Kinzie, Ana K., "Colorism in Mexico: An Examination of Inequality and the Psychological Impact in the Form of Depression" (2021). University Honors Theses. Paper 1089.

https://doi.org/10.15760/honors.1116

This Thesis is brought to you for free and open access. It has been accepted for inclusion in University Honors Theses by an authorized administrator of PDXScholar. Please contact us if we can make this document more accessible: pdxscholar@pdx.edu. 
Colorism in Mexico: An Examination of Inequality and the Psychological Impact in the Form of Depression

by

Ana K. Kinzie

An undergraduate honors thesis submitted in partial fulfillment of the

requirements for the degree of

Bachelor of Arts

in

University Honors

and

Psychology

Thesis Adviser

Marcus Sharpe

Portland State University 


\begin{abstract}
Mexican society is engaging in racism in the form of colorism; while colorism is widespread, it is not acknowledged by the population. As a previous Spanish colony, the effects of the social caste system affect how Mexicans view themselves and others, creating a preference for lighter skin tones. The idea of Mexicans being a hybrid race (Mestizo) prevails in the country, which affects racial minorities as they are often ignored. Skin tone in Mexico can affect the socioeconomic status of their population and the chances of social mobility. While research on how colorism affects the mental health of Mexicans is limited, studies across the world demonstrate that being stigmatized and having internalized colorist ideologies can affect negatively an individual's mental health. Colorism is often learned at a young age and it is correlated with higher levels of depression and poor mental health. The findings suggest that colorism affects different aspects of life and that this type of discrimination is not exclusive to a single racial group. Some consequences of colorism in Mexico include being a target for violence and police brutality. The need to further research on how colorism affects Mexicans is urgent.
\end{abstract}

Keywords: Colorism, depression, Mexico, socioeconomic status. 


\section{Introduction:}

Mexico is a country with racism that has been hidden and denied for hundreds of years (Palacios, 2020); as a previous Spanish colony, Mexico received immigrants from Europe to conquer the new land and slaves from Africa, who were kidnapped and brought to America to support the new labor demand. This event detonated a mix of races and ethnicities, which marked the country's history, where an identity of belonging to a hybrid race emerged. Mexico gained its independence from Spain more than 200 years ago, yet there is still a prevalence of the mindset of colonial White superiority. Even though the Mexican society argues that their nation is divided by socioeconomic status, there is a correlation between skin tone and status.

Colorism is defined as "prejudice or discrimination especially within a racial or ethnic group favoring people with lighter skin over those with darker skin” (Merriam-Webster, n. d.). Research has shown that in Mexico, your skin color can affect your chances of getting a job, having education and owning material goods (Solís et al., 2019), which affects crucial aspects of an individual's life such as having better chances of moving in the social hierarchy and accessing resources. There is also a lack of acknowledgment to the Afro-Latino population living in the country; Many people believe that the cultural mix consists only of Indigenous and European ancestors, ignoring the African roots many Mexicans have and the disadvantages they face (Solís et al., 2019). While colorism in Mexico is just starting to get more acknowledgment, there is a need to research the effects it is having on its society and the mental health of the people being affected by it. Even though the research in Mexico regarding colorism and mental health is scarce, analyzing the research occurring in other countries and other racial groups can indicate 
the consequences colorism has on the mental health of individuals suffering it and how this could correlate with the colorism occurring in Mexico.

This research will analyze the current literature and research regarding colorism in Mexico and find patterns on the larger discourse community that could indicate that colorism is not only affecting the socioeconomic status of the population, but it is also influencing mental health, focusing on symptoms of depression and the consequences this could have on the affected population. By analyzing research on colorism, there will be a discussion of how the findings in other research can also explain the mental health crisis in the form of depression in people who suffer from this type of discrimination in Mexico. To analyze if colorism in Mexico is causing psychological distress in the form of depression on the people affected, the historical background and socioeconomic background of colorism in Mexico will be discussed.

\section{Methods}

This thesis will analyze three main aspects to understand the problem of colorism in Mexico: the history of colorism in Mexico, the socioeconomic effects it has on the population, and the current research regarding the psychological effects of colorism, focusing on depression. A literature review will be conducted to highlight the research occurring in regards to Colorism. Due to the lack of research in Mexico regarding the psychological effects of Colorism, this review will include research conducted on a larger scale in other countries and racial groups in order to find correlations with the situation Mexico is living in. The goal is to understand the measures currently being used in the field, see how they could also apply in Mexico, and focus on promoting further research in colorism in the country. 


\section{Historical Background}

The preference for lighter skin color has a root in the history of Mexico; when the Spanish conquerors arrived in Mexico in 1518, they viewed the native population as "heathens" who needed to be civilized, an idea that was based upon the European concept of the world beyond them and which ignited the first differences between White Europeans and non-White people who lived in Latin America (Chavez Dueñas et al., 2014). Indigenous people were subjected to European standards, where they were expected to merge into their religious ideas and were exploited for the profit of the Spaniards. The Spanish colonizers also brought slaves from Africa to help with the labor, since the indigenous population significantly declined after their arrival due to the conditions they were subjected to and the diseases the Spaniards brought with them (Bacci, 2008).

Once all these races collided in Mexico, there was an emergence of a caste system, which helped stratify the population by skin color and phenotypic characteristics; White people were placed at the top of the social hierarchy, while Indigenous and African people with darker skin complexion were placed at the bottom (Chavez Dueñas et al., 2014). Spanish civil and ecclesiastical authorities emphasized racial differences as a way of exerting their control over the population (Katzew, 1996) As Figure 1 demonstrates, the Spaniards were at the top of the hierarchy, which benefited the roles they could achieve in society and this was heavily correlated with their skin color. As part of the colonization process, the mixing between Spanish and Indigenous, Indigenous and Africans, etc. occurred, creating diversity in the country, but where these groups were heavily segregated based on their ancestry and their physical characteristics. 


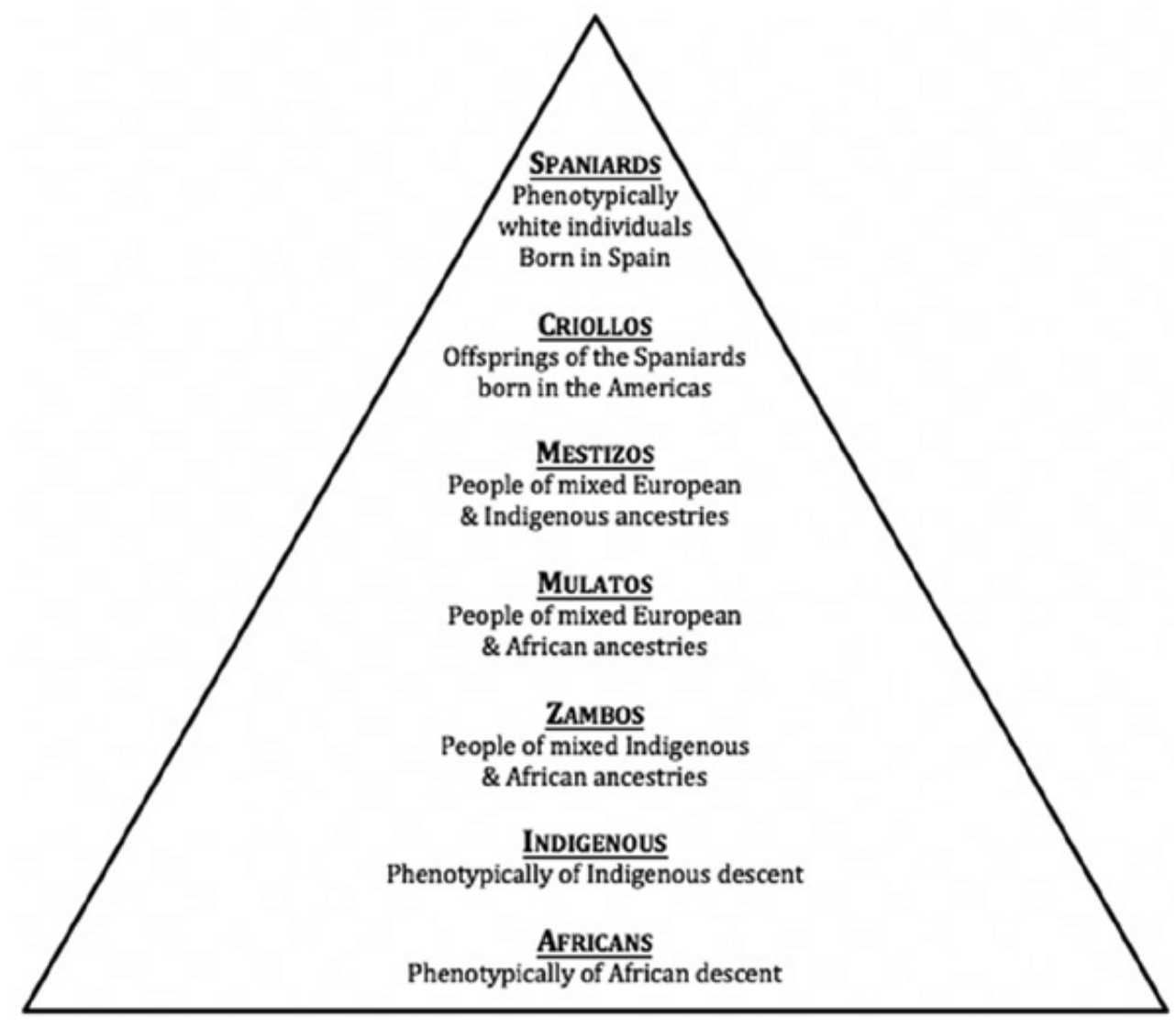

Figure 1: Latin American Social Caste Pyramid (LASCP).Note. Informed by the 18th-century Latin American family caste paintings by Miguel Cabrera (Katzew, 1996). Racial mix determined hierarchy, social status, and economic privilege. Reprinted from Chavez Dueñas N. Y., Adames H. Y., Organista K. C. (2014). Skin-Color Prejudice and Within-Group Racial Discrimination: Historical and Current Impact on Latino/a Populations. Hispanic Journal of Behavioral Sciences., 36(1), 3-26.

Mexico gained its independence from Spain around 1830, after spending hundreds of years under the control of colonialism (Livi-Bacci, 2008). Even though they were not under the power of the Spanish, the ideas of white superiority and the broken social system prevailed. The idea of Mexicans being a hybrid race started to be promoted too, but there were problems with 
that ideology; the Iguala Plan (Plan de Iguala) from 1822, emphasized to omit in any kind of document the racial origins of individuals, which affected Indigenous people when trying to receive benefits and trying to maintain their land since they had a harder time proving their origins and the laws could take their belongings (Navarro, 1968). Even though there were attempts to connect the different racial groups in Mexico, the process ended up affecting Indigenous and Black individuals.

Even though the process of racial mixing occurred during the colonial period, it did not happen on a larger scale until the nineteenth century (Navarrete, 2016). This occurred when White men started having children with Indigenous women on a larger scale and when capitalist modernization started to enter the country, which pushed the country to attempt to have more unity. Between 1850 and 1950, Mexicans started to speak the same language (Spanish), have the same social values and cultural identities, which formed the "Mestizo" identity (Navarrete, 2016). José Vasconcelos's work, "The Cosmic Race" which was published in 1925, brought the idea of the nation's embrace of racial hybridity by being Mestizos, where Mexicans were a product of the inevitable mixture of races, which was superior from being a "pureblood" and therefore Mexico was free of racist beliefs and practices (Bodenheimer, 2012). This portrayed Indigenous people as the past of Mexico and promoted the idea that they could incorporate into the Mestizo race, yet it did not acknowledge the African descendants who also inhabited the country and formed an important part of the population. The conflict with this ideology is that it did not acknowledge the socioeconomic differences that were present in the country deriving from racial origins and how the appearance of an individual still affected the chances for social mobility and owning goods. 
Compared to other Latin countries, Mexico has a small African descendant population, which is popular when trying to identify colorism, and therefore this group gets often ignored, yet they are part of the most affected groups by colorism (Solís et al., 2019; Villareal, 2010 ). The National Institute of Statistics and Geography (INEGI) incorporated in 2015 for the first time in their polls an option to identify their Black population, Afromexican or Afro Descendant (Solís et al., 2019). This question involves cultural auto description, yet it progresses into recognizing this part of the population and changing the idea of mestizaje being a product of only European and Indigenous people. The lack of previous data makes it hard to analyze this group, which has been historically excluded from Mexico, even though they have been there for hundreds of years.

Nowadays, many Mexicans have problems with identifying their ethnic and racial background, but most of them identify as Mestizos (Solís et al., 2020). The conflict with that is that they are not able to see the discrimination and differences occurring among them based on how they look and their skin color because they believe they all belong to the same ethnic and racial group and are divided by socioeconomics. According to Navarrete (2016), “As long as we Mexicans continue to think of ourselves as mestizos, we cannot stop being racists."

\section{Socioeconomic Background}

Even though there are social disadvantages caused by colorism, people have not acknowledged colorism as a problem in their society; skin color in Mexico can play an important role in how people perceive each other, the level of education an individual can accomplish, the jobs that one can have access to and even the chances of having an opportunity for a leadership 
position, such as running for a spot in politics. The 2019 PRODER poll made it possible to see characteristics in categories such as ethnicity and race and how these correlate to important social and economic factors (Solís et al. 2020). What also made this poll innovative is that for the first time in Mexico, the poll was able to use optical methods to collect information about skin color in adults, taking away the auto-description of skin color and the perception of the people realizing the poll about the subject's skin color, leaving less room for bias from both parties. The study demonstrated that the people realizing the poll tended to identify individuals with a lighter skin tone and that this phenomenon was more present when the people surveyed had more education or higher socioeconomic status (Solís et al., 2020). The results also exposed how there is a persistent association of skin color with socioeconomic status; people with the darkest skin tones tend to be part of the poorest $20 \%$ of the population and people with the lightest skin tone predominated in the richest $20 \%$. The association between skin color and socioeconomic status is present and the disadvantages people suffer make it harder to progress in aspects such as jobs available and education.

As Campos-Vazquez \& Medina-Cortina (2018) discuss, there is a lack of census data regarding skin color due to the assumption that what affects social mobility in Mexico are the education levels and socioeconomic status rather than the race and appearance. Skin color in Mexico has an influence on the economy and educational level an individual can achieve, yet it also plays a role in cognitive and noncognitive skills and time spent with parents (Campos-Vazquez \& Medina-Cortina, 2018). Even though this is recently being researched, these inequalities have been carried from one generation to another, where families are stuck in the same level of low education and job opportunities. People with lighter skin color do have 
more schooling and have a better economic status, from better positions to better wages. There is also a relationship between the income the participants were making and what their parents were making with skin color, a phenomenon that affects social mobility (Campos-Vazquez \& Medina-Cortina, 2018). People with the darkest skin tone have the lowest levels of wealth distribution and education. There are also geographical correlations with skin color, where the South has a population with darker skin, Central Mexico has an abundance of Mestizos and the North has a larger concentration of population with lighter skin tones (Villareal, 2010). This correlates with which regions of the country have more economic growth and bigger cities.

The association between your ethnic-racial background could also be influencing your socioeconomic status by conditioning your life opportunities or people's opportunities could be influencing how they describe themselves (Solís et al., 2020). Racial phenotypes play an important role in Mexican society, affecting how people view others and the racist ideas they have of certain groups (Aguilar, 2011). The impact of ethnic distinction in Mexico is not only focused on how people look, but also on what cultural practices people follow and if they speak an Indigenous language (Villarreal, 2010). There is a self-fulfilling prophecy about Indigenous people being uneducated, conforming easily, and being poor, which sets the group in a disadvantageous position (Aguilar, 2011). According to Solis et al (2020), there was a pattern of describing oneself as Mixed Race when there were higher levels of education involved. There is a system of social stratification caused by skin color, where the population with darker skin tones have significantly lower levels of education and have lower-wage jobs, which shows the effects of post-colonial ideologies still affecting Mexico. 
According to Villareal (2010), even though there is no clear system for categorizing skin color, there is a tendency for Mexicans to prefer lighter skin color and European features, even though historically they are a "Mestizo" country. There are passive ways in which Mexicans acknowledge their preference for lighter skin by using phrases in their everyday life that include racist ideas of having certain phenotypes, such as darker skin color (Chavez Dueñas et al., 2014). Figure 2 provides some examples of phrases that are commonly used in Mexican culture, yet they have racist undertones.

\begin{tabular}{|l|l|}
\hline Phrase: & Meaning: \\
\hline Hay que mejorar la raza & $\begin{array}{l}\text { We have to improve the race (alleges to } \\
\text { marrying a White individual to have } \\
\text { lighter-skin children) }\end{array}$ \\
\hline Trabajo como negro para vivir como blanco & I work like a Black to live like a White \\
\hline El niño está morenito, pero aun así esta bonito & The child has dark skin, but it is still pretty \\
\hline Eres bien naco & $\begin{array}{l}\text { You are low-class/uncultured (Often used in } \\
\text { a derogatory manner towards darker-skinned } \\
\text { individuals) }\end{array}$ \\
\hline $\begin{array}{l}\text { No tiene la culpa el indio, sino el que lo hace } \\
\text { compadre }\end{array}$ & $\begin{array}{l}\text { It is not only the error of the person who } \\
\text { committed it but also from the person who } \\
\text { assigned the responsibility (It assumes } \\
\text { Indigenous people are incapable of making } \\
\text { hard tasks) }\end{array}$ \\
\hline
\end{tabular}

Figure 2: Popular phrases from the Mexican language that are racist. 
The preference for lighter skin also varies between genders; females tend to identify with lighter skin tones than men (Villareal, 2010). The preference for lighter skin also affects how people perceive one another and how they perceive themselves. The aspirations an individual has are closely related to the stereotypes based on their skin color (Campos-Vazquez \& Medina-Cortina, 2017). Social mobility can be affected by this since young people are making decisions based on the expectations they have based on their skin color (Campos-Vazquez \& Medina-Cortina, 2017). In an experiment trying to figure out if racial phenotypes affect aspects of society, such as politics, participants were required to choose a politician, where the candidates had different racial features. The results demonstrated that people have a preference for a Whiter candidate over a Mestizo or Indigenous one with similar qualifications (Aguilar, 2011). The disadvantages and stereotypes are present in all levels of society and they can affect our decision-making and our preferences for who we choose to put on top of our social hierarchy. Having certain stereotypes and expectations of society based on appearance can affect how people interact with each other and how they think about themselves.

\section{Psychological Effects}

While research regarding the psychological effects of colorism in Mexico is scarce, there is a need to acknowledge colorism could be affecting the mental health of its population. While originally being mostly focused on Black people, scholars are beginning to recognize that the impact colorism has is much broader than it had originally been conceptualized and they are beginning to analyze the different ways in which it manifests among individuals and groups across the world (Woodson, 2020). An individual's cultural heritage may superimpose 
expectations about racialization experiences (Burton et al, 2010); This can affect how people will view colorism. There is a lack of attention to colorism and how it shapes race/ethnic socialization practices of families, specifically with people from countries with racialized and color-conscious hierarchies. (Burton et al, 2010).

In order to analyze some of the psychological effects colorism may have on the mental health of Mexicans, research conducted on the psychological effects of colorism in other countries and racial groups will be discussed to emphasize the risks of colorism and how these findings could also be occurring in Mexico. Colorism is a much more pervasive and global phenomenon than originally thought (Woodson, 2020). The effects colorism has on the mental health of individuals suffering from it is a topic with growing research. Colorism is a source of trauma that may cause self-destructive behaviors, acting out, and negative coping mechanisms (Burton, et al. 2010; Woodson, 2020). Learning about how this phenomenon occurs globally can promote further research in Mexico.

\section{Growing up with Colorism}

The psychological effects of colorism start when being exposed to it at an early age; color biases appear to be internalized in early life and this can affect a developing child's mind (Burnett, 2015). These biases have an origin in comments about color from family members, friends, and peers, which can get carried to adulthood (Woodson, 2020). The use of nicknames describing skin color in a derogatory manner when referencing a darker skin complexion also indicates colorist ideologies and can affect the self-esteem of individuals who are associated with these "color names" (Wilder, 2010). According to Hill (2002), many children of color are aware of the privileges associated with lighter skin colors and long to share those advantages. These 
unresolved colorist ideologies can cause guilt, anger, jealousy, and depression in children (Woodson, 2020). While these events may not be purposely caused by the parents and peers, children are learning about racial biases and they can be hurtful for their mental health. Family can perpetuate skin tone consciousness and bias, which can create feelings of inadequacy, especially in women (Wilder \& Cain, 2011). This exposure plays into how they perceive themselves, how others perceive them, and their expectations of how they should be treated (Woodson, 2020). According to Burnett (2015), this kind of exposure to racial biases can have negative effects on the development of a child's self-esteem and self-worth; having poor self-esteem can increase the likelihood of engaging in disruptive behaviors such as substance abuse, criminal acts, promiscuity, etc. Learning at a young age about these biases affects the development of these individuals, which can cause learned helplessness and feel inferior (Wilder \& Cain 2011). While this develops in childhood, the effects can be prolonged into adulthood, especially if they are not addressed (Burnett, 2015). As Woodburn (2020) emphasizes, clinicians who are working with this population are noticing the effects of internalized colorism; they are inclined to suffer mood disorders, such as depression, anxiety disorders, and personality disorders.

\section{Colorism and Depression}

Colorism affects the psychological well-being of individuals; According to the American Psychiatric Association (2013), depression is a medical illness that affects how you feel, think, and act by causing feelings of sadness and a loss of interest in activities that an individual once enjoyed. Research indicates that perceived racial discrimination among people with darker skin 
color can have negative effects on mental health, contributing to symptoms of depression and anxiety (Pinkston, 2016). Suffering discrimination based on skin color can create stigma on the individuals being targeted by it; Stigma-related stressors such as skin color can undermine mental and physical health (Chaudoir et al, 2013). Experiencing this type of stigmatization can be stressful and can create negative ideas of oneself that can affect the individual's mental health. According to Mena et al. (2020), the research on Latinos and non-Latino Blacks analyzing the influence of skin tone on health conclude that having a darker skin tone is associated with poorer psychological adjustment. Individuals with darker skin reported less satisfaction with their skin tone, which was negatively associated with anxiety and depression (Mena et al., 2020). According to Woodson (2020), unresolved colorist ideologies can give rise to diagnostic concerns like narcissism, depression, anxiety, PTSD, disordered eating, and facial/ body dysmorphia.

Colorism is linked to beauty standards, where there is a preference for eurocentric phenotypes and lighter skin color (Pinkston, 2015; Hunter, 2016). Colorism acknowledges White and Anglo phenotypes as valuable, positive traits are associated with Whiteness, and negative traits are associated with Blackness or Indigeneity (Hunter, 2016). According to Hochschild \& Weaver (2007), individuals with darker skin tones acknowledge that they would prefer a lighter skin tone and more Eurocentric features and this is more prevalent among females. Having negative images of oneself contributes to negative ideas of how you feel and think about yourself. This type of message affects women on a larger scale, which contributes to psychological distress in the form of lower self-esteem and feelings of inferiority (Hall, 2017). In 
an attempt to look more White and attractive according to societal expectations, there is a widespread production of beauty creams across different societies that are used to make skin lighter. (Tummala-Narra, 2007). These products are harmful to an individual's health, yet they are a popular business in Asian, African, and Latin countries (Tummala-Narra, 2007; Hall, 1994 \& Woodson, 2020). Associating beauty with Whiteness is a phenomenon that affects both physical and mental health. As Pinkston (2016) mentions, individuals who are discriminated against due to colorism are at a higher risk of suffering from lowered self-esteem related to their romantic relationships, occupation, perceived physical attractiveness, and competence. As Fuentes et al. (2021), highlight: "The literature is in agreement: skin color seems to have a negative impact on those perceived to be darker-skinned".

Darker skin tones have been associated with how much propensity an individual has to suffering depression; research conducted by Khan et al. (2017), demonstrated that factors such as chronic strain and stressful life events were risk factors for depression, and these factors were correlated with suffering discrimination. These factors were also positively associated with increased odds of suffering depression (Khan et al., 2017). According to Codina \& Montalvo (1994), having a darker skin tone is associated with higher levels of depression among US-born Mexicans, and having Indigenous phenotypes is also correlated with suffering depression. Black Latinos reported the highest levels of depressive symptoms compared to European Americans and African Americans, showing how being part of a double minority could affect mental health (Ramos et al., 2003; Mena et al., 2020). The psychological effects of colorism are noticeable in different groups around the world and even though research in Mexico is limited, learning how 
the population is being affected by analyzing research can help understand the urge to study this further. Colorism affects all aspects of life and it causes negative consequences in those who suffer it.

\section{Consequences of Colorism}

Colorism can be an indicator of how people can be a victim of aggression and how they will respond to violence. In Mexico, your skin color can make you a target for violence; according to the Instituto Nacional de Los Pueblos Indígenas (National Institute of Indigenous Towns), 45.5\% of Indigenous women reported suffering from emotional violence (INPI, 2017). Homicides occurring in Indigenous communities have been on the rise and it is associated with the low levels of marginalization they suffer compared to the rest of the country (Frías, n.d.). The people who live in Indigenous communities live an average of 10 to 20 years less than the rest of the population (Jiménez, n.d.). Mexico also has a problem with femicides; according to the World Health Organization (2012), femicide is when there is intentional murder of women because they are women, but the broader aspect also includes the killings of women or girls. Indigenous women are often absent from conversations about femicide, even though Indigenous people are over 15 percent of Mexico's population (Eagan, 2020). Since they have some of the worst economic conditions, they are often exposed to unsafe experiences. Mexico has a problem with cartels and one of their biggest illegal industries is human trafficking; approximately seventy percent of human trafficking victims are Indigenous women (Eagan, 2020).

Your skin color can also affect how you will be treated by the police; on March 27th 2021, Victoria Salazar was murdered by the police in Tulum, Mexico (Diaz, 2021; The Guardian, 
2021). The 36-year-old Salvatorian immigrant was murdered after policemen kneeled on her neck; Victoria's case is one of the many cases of violence against immigrants in Mexico. As Diaz (2021) mentions, migrants are regularly targeted by criminal gangs, Mexican police, and government officials who often are related to gangs. One of Mexico's most horrible mass killings occurred on the 26th of September 2014 in the small town of Iguala, Guerrero when 43 students from Ayotzinapa were attacked by the police and military (Navarrete, 2016; Mexico News Daily, 2020). The students were traveling to protest in Mexico City when they were intercepted by corrupt policemen who handed them to a local gang, the Guerreros Unidos (Mexico News Daily, 2020). To this day no one has been charged for this heinous crime. This is another example of how there is impunity caused by police, yet compared to most cases, this one caused a great outcry from the public, giving the victims a face, yet no justice. Mexico has its own battle with a racist police system, where belonging to a certain group or having certain phenotypes can make you a victim (Cabrera, 2021). As Navarrete (2016) mentions, the relationship between racism in Mexico and violence is evident, as there are countless victims who remain invisible to the system, even after a tragic death.

\section{Discussion and Limitations}

Even though the psychological effects of colorism in Mexico have not received a focal point in research, there is a need to promote investigating this topic. Colorism in Mexico is very widespread but it is not often talked about and the idea of the "Mestizo" race diminishes the differences that have to be acknowledged. Using Mestizaje as a social and symbolic construction has minimized identities by considering them inferior if they do not belong to the Indigenous and 
Occidental clash (Palacios, 2020). As Mena et al. (2020) mention, the literature on racial identity, skin tone satisfaction, and psychological adjustment has largely approached black individuals as a single racial group in the USA when there is a significant and growing proportion of Latinos that also claim a black racial identity. Colorism goes beyond races and countries and Mexico needs to acknowledge they are engaging in racism. As Burnett (2015) mentions, "colorism is a painful and shameful reminder of our tortuous past".

The examples portrayed in this research are just a glimpse into the problem that colorism encompasses; As Chavez Dueñas \& Adames (2016) stated, studying Latino psychology points to one overarching fact; racism continues to play a role in society and harms everyone in it. This research is not an empirical study but its goal is to recognize the psychological effects of colorism and how the conditions in Mexico can contribute to depression in its population. It is important to recognize that Mexico is engaging in racism so they can take action to help the vulnerable population. The need for engaging in political action to make the differences fade, recognizing the historical effects of colorism, and pursuing the research of the psychological effects of colorism are some steps that need to be taken. Mexico has been engaging in negative behaviors and there is a need for immediate action. 
References

Adames, H.Y., \& Chavez-Dueñas, N.Y. (2016). Cultural Foundations and Interventions in Latino/a Mental Health: History, Theory and within Group Differences (1st ed.). Routledge. https://doi-org.proxy.lib.pdx.edu/10.4324/9781315724058

Aguilar, R. (2011). Social and Political Consequences of Stereotypes Related to Racial Phenotypes in Mexico. CIDE Working Papers, (230), 1-21.

American Psychiatric Association. Diagnostic and Statistical Manual of Mental Disorders (DSM-5), Fifth edition. 2013.

Bacci, M. L. (2008). Conquest: the destruction of the American Indios. Polity.

Bodenheimer, R. (2012, November 22). Mestizaje in Latin AMERICA: Definition and history. Retrieved from https://www.thoughtco.com/mestizaje-in-latin-america-4774419

Burnett, N. (2015). Colorism in mental health: Looking the other way. Journal of Colorism Studies, 1(1), 1-5. Retrieved from http://stats.lib.pdx.edu/proxy.php?url=http://search.proquest.com.proxy.lib.pdx.edu/schol arly-journals/colorism-mental-health-looking-other-way/docview/1661718383/se-2?acco untid $=13265$

Burton, L., Bonilla-Silva, E., Ray, V., Buckelew, R. \& Freeman, E.H. (2010). Duke University critical race theories: Colorism, and the decade's research on families of color. Journal of Marriage and Family: 440 - 459. DOI:10.1111/j.1741- 3737.2010.00712.x 
Cabrera, K. (2021, April 12). Mexico has its own movement against police brutality. Retrieved May 18, 2021, from https://www.kut.org/crime-justice/2021-04-12/mexico-has-its-own-movement-against-pol ice-brutality

Campos-Vázquez, R., \& Medina-Cortina, E. (2017). Identidad social y estereotipos por color de piel. Aspiraciones y desempeño en jóvenes mexicanos. El Trimestre Económico, 85(337), 53-79. https://doi.org/10.20430/ete.v85i337.659

Campos-Vazquez, R. \& Medina-Cortina, E. (2018). Skin Color and Social Mobility: Evidence From Mexico. Demography, 56(1), 321-343. https://doi.org/10.1007/s13524-018-0734-z

Chaudoir, S. R., Earnshaw, V. A., \& Andel, S. (2013). "Discredited" Versus "Discreditable": Understanding How Shared and Unique Stigma Mechanisms Affect Psychological and Physical Health Disparities. Basic and Applied Social Psychology, 35(1), 75-87.

Chavez Dueñas N. Y., Adames H. Y., Organista K. C. (2014). Skin-Color Prejudice and Within-Group Racial Discrimination: Historical and Current Impact on Latino/a Populations. Hispanic Journal of Behavioral Sciences., 36(1), 3-26. https://doi.org/info:doi/

Codina, G. E., \& Montalvo, F. F. (1994). Chicano phenotype and depression. Hispanic Journal of Behavioral Sciences, 16(3), 296-306.

Diaz, N. (2021, March 31). 36-year-old Salvadoran mother killed by Mexican police officer. Retrieved May 18, 2021, from https://www.wsws.org/en/articles/2021/04/01/tulu-a01.html 
Eagan, M. (2020, November 30). Indigenous Women: The Invisible Victims of Femicide in Mexico. Harvard International Review. https://hir.harvard.edu/indigenous-women-victims-of-femicide-in-mexico/.

Frías, S. M. (n.d.). Primer Diagnóstico Nacional sobre Violencias en Contra de las Mujeres y Niñas Indígenas. https://www.gob.mx/cms/uploads/attachment/file/417665/cdi-diagnostico-violencias-cont ra-mujeres-ninas-indigenas.pdf.

Fuentes, M. A., Reyes-Portillo, J. A., Tineo, P., Gonzalez, K., \& Butt, M. (2021). Skin Color Matters in the Latinx Community: A Call for Action in Research, Training, and Practice. Hispanic Journal of Behavioral Sciences, 0739986321995910.

Hall, J. C. (2017). No longer invisible: Understanding the psychosocial impact of skin color stratification in the lives of African American women. Health \& Social Work, 42(2), $71-78$

Hall, R. E. (1994). The "Bleaching Syndrome": Implications of Light Skin for Hispanic American Assimilation. Hispanic Journal of Behavioral Sciences, 16(3), 307-314. https://doi.org/10.1177/07399863940163008

Hill, M. (2002). Skin Color and the Perception of Attractiveness among African Americans: Does Gender Make a Difference? Social Psychology Quarterly, 65(1), 77-91. doi:10.2307/3090169

Hochschild, J. L., \& Weaver, V. (2007). The skin color paradox and the American racial order. Social Forces, 86(2), 643-670. doi:http://dx.doi.org.proxy.lib.pdx.edu/10.1093/sf/86.2.643 
Hunter, M. (2016). Colorism in the classroom: How skin tone stratifies African American and Latina/o students. Theory Into Practice, 55(1), 54-61.

INPI | Instituto Nacional de los Pueblos Indígenas. (2017, November 25). Datos e indicadores sobre violencia contra las mujeres indigenas. gob.mx. https://www.gob.mx/inpi/articulos/datos-e-indicadores-sobre-violencia-contra-las-mujere s-indigenas.

Jiménez, M. P. (n.d.). Violencia contra las Mujeres Indígenas. . http://escuelapueblosindigenas.cndh.org.mx/assets/doc/Ponencias/P-Marina-M9.pdf.

Katzew, I. (1996). Casta painting: Identity and social stratification in colonial Mexico. New world orders: Casta painting and colonial Latin America, 8-29.

Khan, M., Ilcisin, M. \& Saxton, K. (2017). Multifactorial discrimination as a fundamental cause of mental health inequities. Int $J$ Equity Health 16, 43. https://doi.org/10.1186/s12939-017-0532-z

Martínez-Echazábal, L. (1998). Mestizaje and the Discourse of National/Cultural Identity in Latin America, 1845-1959. Latin American Perspectives, 25(3), 21-42. https://doi.org/10.1177/0094582X9802500302

Mena, J. A., Soto, J. A., Wei, W., Kaplan, S. E., \& Salazar, S. (2020). Does centrality moderate the relation between skin tone satisfaction and psychological adjustment in Latinx Blacks and non-Latinx Blacks? Race and Social Problems, 12, 219-232.

Merriam-Webster. (n.d.). Colorism. In Merriam-Webster.com dictionary. Retrieved April 11, 2021, from https://www.merriam-webster.com/dictionary/colorism 
Mexico News Daily. (2020, September 29). Warrants issued for military, police in connection with Ayotzinapa case. Retrieved May 18, 2021, from https://mexiconewsdaily.com/news/warrants-issued-for-soldiers-police-in-connection-wit h-ayotzinapa-case/

Navarrete Linares, F. (2016). México racista: Una denuncia (Primera edición). Grijalbo.

Navarro, M. (1968). El mestizaje mexicano en el periodo nacional. Revista Mexicana De Sociología, 30(1), 35-52. doi:10.2307/3539019

Palacios, A. P. (2020, January 23). Colorismo, lo Añejo del Racismo y Otras Formas de Discriminación en México - PUEBLA -. Retrieved April 11, 2021, from $\underline{\text { https://www.lajornadadeoriente.com.mx/puebla/colorismo-lo-anejo-del-racismo-y-otras-f }}$ ormas-de-discriminacion-en-mexico/

Pinkston, T. M., "Cues of Colorism: The Psychological, Sociocultural, and Developmental Differences between Light-skinned and Dark-skinned African-Americans" (2015). Electronic Theses and Dissertations. 1300. https://digitalcommons.georgiasouthern.edu/etd/1300

Ramos, B., Jaccard, J., \& Guilamo-Ramos, V. (2003). Dual ethnicity and depressive symptoms: Implications of being Black and Latino in the United States. Hispanic Journal of Behavioral Sciences, 25(2), 147-173.

Solís P., Avitia M. \& Güémez B. (2020) Tono de piel y desigualdad socioeconómica en México. Reporte de la Encuesta Proder \#1

https://discriminacion.colmex.mx/wp-content/uploads/2020/07/info1.pdf. México: El Colegio de México. 
Solís, P.,. Güémez, B. \& Avitia, M. (2020). Autoadscripción étnico-racial en México. Reporte de la Encuesta Proder \# 2. https://discriminacion.colmex.mx/. México: El Colegio de México.

Solís, P., Güémez, B., \& Lorenzo, V. (2019). Por mi raza hablará la desigualdad. Efectos de las características étnico-raciales en la desigualdad de oportunidades en México. OXFAM México.

The Guardian. (2021, March 29). Mexico: Tulum police accused of 'murder' over death of woman knelt on by officers. Retrieved May 18, 2021, from https://www.theguardian.com/world/2021/mar/29/victoria-salazar-mexico-tulum-police-o fficers-charged-woman-dies-arrest

Tummala-Narra, P. (2007). Skin color and the therapeutic relationship. Psychoanalytic Psychology. 24. 255-270. 10.1037/0736-9735.24.2.255.

Villarreal, A. (2010). Stratification by Skin Color in Contemporary Mexico. American Sociological Review, 75(5), 652-678. https://doi.org/10.1177/0003122410378232

WHO. (2012). Femicide. Understanding and addressing violence against women. https://apps.who.int/iris/bitstream/handle/10665/77421/WHO_RHR_12.38_eng.pdf;jsessi onid=DB099BCD2AD4D251EEEA4436ED09C2B1? sequence=1.

Wilder, J. (2010). Revisiting "color names and color notions" a contemporary examination of the language and attitudes of skin color among young black women. Journal of black studies, 41(1), 184-206. 
Wilder, J., \& Cain, C. (2011). Teaching and learning color consciousness in Black families:

Exploring family processes and women's experiences with colorism. Journal of family issues, 32(5), 577-604.

Woodson, K. M. (2020). Colorism: Investigating a Global Phenomenon. Fielding University Press. 